\title{
GAYA KEPEMIMPINAN KEPALA SEKOLAH DALAM MENGEMBANGKAN KINERJA PENDIDIK
}

\author{
Nursam \\ Institut Agama Islam Negeri Palopo \\ E-mail:syam1954783@gmail.com
}

\begin{abstract}
Abstrak
Penelitian ini bertujuan untuk mendsikripsikan gaya kepemimpinan kepala sekolah di SMP Negeri 2 Baebunta, untuk mengetahui kinerja guru di SMP Negeri 2 Baebunta, untuk mengetahui factor internal yang berkontribusi dalam mengembangkan kinerja pendidik di SMP Negeri 2 Baebunta, serta untuk memahami faktor eksternal yang berkontribusi dalam mengembangkan kinerja pendidik di SMP Negeri 2 Baebunta. Penilitian ini bersifat kualitatif dengan pendekatan religious, pedagogic, dan pendekatan manajerial. Data diperoleh menggunakan observasi, wawancara, dan dokumentasi. Data dianalisis dengan reduksi data, penyajian data, triangulasi dan peanrikan kesimpulan. Hasil penelitian menunjukkan bahwa gaya kepemimpinan kepala sekolah di SMP Negeri 2 Baebunta umumnya menggunakan gaya demokratis namun terkadang menggunakan gaya otoriter apabila diperlukan. Kinerja Penampilan guru SMP Negeri 2 Baebunta sesuai dengan yang diharapkan kepala sekolah sesuai dengan perencanaan, pelaksanaan dan berjalan dengan baik begitupula dengan hasil kinerja guru meliputi penilaian UTS dan nilai UAS siswa yang baik. Faktor internal terdiri dari kekuatan dan kelemahan mencakup sarana dan prasarana, guru, serta kepemimpinan kepala sekolah. faktor eksternal terdiri dari peluang dan tantangan dapat dilihat dari kebijakan pemerintah, teknologi informasi dan komunikasi, dan kerja sama antara pihak sekolah.
\end{abstract}

Kata Kunci: Gaya Kepemimpinan Kepala Sekolah, Kinerja Pendidik

\begin{abstract}
The aims of this reseach to describe the leadership style of the head school at SMP Negeri 2 Baebunta to determine the performance of teachers in at SMP Negeri 2 Baebunta, to know the internal factors that contribute to developing the performance of educators in SMP Negeri 2 Baebunta, and to understand external factors that contribute in developing the performance of educators at SMP Negeri 2 Baebunta. This research is qualitative research that uses a religious approach, pedagogic approach, and managerial approach. Data collected by observation, interview and documentation. Data analyzed using by data reduction, data display, triangulation and conclusion. The result shows that leadership style of the principal of SMP Negeri 2 Baebunta applies decocratic style but apply authoritarian leadership when it is needed. Performance of teachers in SMP Negeri 2 Baebunta are accordance with the expectation of the principal where planningof learning, implementation of learning and the implementation of assessment have been going well likewise with the result of teachers' performance includes the assessment of UTS and the UAS values are well. Internal factors consist strength and weakness include facilities and infrastructure teachers, and leadership of principal. External factor consist of opportunities and challenges can be seen from government policies, information and communication technology, and cooperation between the school parties.
\end{abstract}

Keywords: Principal Leadership Style, Educator Performance 


\section{8 | Nursam}

\section{Pendahuluan}

Kepala sekolah sebagai pemimpin pendidikan mengahadapi tanggung jawab yang berat, dalam menghadapi segala permasalahan dan tantangan yang dihadapi untuk menciptakan dan memberikan kenyamanan bagi guru dan siswa di sekolah. Kemampuan kepala sekolah dalam memimpin sangat berperan dalam mengembangkan kerja guru maupun mengembangkan dan menciptakan proses pembelajaran efektif dan tepat sasaran. Dalam proses kepemimpinan dikenal gaya kepemimpinan yang biasa digunakan pemimpin dalam melaksanakan tanggung jawabnya memimpin suatu organisasi.

Kepemimpinan berasal dari akar kata pemimpin, yang berarti seseorang yang dikenal dan berusaha untuk mempengaruhi para pengikutnya, untuk merealisasikan apa yang menjadi visinya. ${ }^{1}$ Hadari Nawawi menyatakan bahwa kepemimpinan adalah proses mengarahkan, membimbing, mempengaruhi atau mengawasi fikiran, perasaan atau tindakan dan tingkah laku orang lain.2Sementara itu, Ngalim Purwanto menyatakan bahwa kepemimpinan adalah sekumpulan dari serangkaian kemampuan dan sifat-sifat kepribadian, termasuk di dalamnya kewibawaan, untuk dijadikan sebagai sarana dalam rangka meyakinkan yang dipimpinnya agar mereka mau dan dapat melaksanakan tugas yang dibebankan kepadanya dengan rela dan penuh semangat, ada kegembiraan batin serta merasa tidak terpaksa. ${ }^{3}$ Kepemimpinan dalam pendidikan dapat diartikan sebagai suatu kesiapan, kemampuan yang dimiliki oleh seseorang dalam proses mempengaruhi, mendorong, membimbing, mengarahkan dan menggerakkan orang lain yang ada hubungannnya dengan pelaksanaan dan pengembangan pendidikan agar segenap kegiatan pembelajaran dapat berjalan secara efektif dan efisien, yang pada gilirannya dapat mencapai tujuan pendidikan yang telah ditetapkan. ${ }^{4}$

Konsep kepemimpinan dalam pendidikan tidak bisa dilepaskan dari konsep kepemimpinan secara umum. Secara formal kegiatan kepemimpinan harus diselenggarakan oleh seseorang yang menduduki posisi atau jabatan tertentu yang di lingkungannya terdapat sejumlah orang yang harus bekerja sama untuk mencapai satu tujuan. Oleh karena itu, kepemimpinan pada dasarnya ialah kemampuan menggerakkan, memberi motivasi dan mempengaruhi orang-orang agar bersedia melakukan tindakan-tindakan yang terarah pada pencapaian tujuan melalui keberanian mengambil keputusan tentang kegiatan yang harus dilakukan. Kepemimpinan juga merupakan proses interaksi antar kedua belah pihak, yaitu seorang pemimpin dan yang dipimpinnya.

${ }^{1}$ Syaiful Sagala, Kemampuan Profesional Guru dan Tenaga Kepemimpinan, (Bandung: Alfabeta, 2009), h. 214.

${ }^{2}$ Hadari Nawawi, Kepemimpinan Menurut Islam, (Yogyakarta: GajahMada University Press, 2001), h. 19.

${ }^{3}$ Ngalim Purwanto, Administrasi dan Supervisi Pendidikan, (Bandung: Remaja Rosdakarya, 2017), h. 86.

${ }^{4}$ Burhanuddin, Analisis Administrasi: Manajemen dan Kepemimpinan Pendidikan, (Jakarta: Bumi Aksara, 1994), h. 65. 
Menurut Mulyasa gaya kepemimpinan adalah suatu norma perilaku yang digunakan seseorang pada saat orang tersebut mencoba mempengaruhi perilaku orang lain seperti yang ia lihat. Gaya kepemimpinan merupakan suatu pola perilaku seseorang pemimpin yang khas pada saat mempengaruhi yang dipimpinnya, apa yang dipilih oleh pemimpin untuk dikerjakan, cara pemimpin untuk bertindak dalam mempengaruhi anggota kelompok membentuk gaya kepemimpinannya. ${ }^{5}$ Dengan demikian gaya kemimpinan kepala sekolah adalah cara yang dipergunakan oleh kepala sekolah dalam mempengaruhi para bawahannya yang ada di sekolah. Gaya kepemimpinan adalah pola tingkah laku yang dirancang sedemikian rupa untuk mempengaruhi bawahannya agar dapat memaksimalkan kinerja yang dimiliki bawahannya sehingga kinerja organisasi dan tujuan organisasi dapat dimaksimalkan. ${ }^{6}$ Sementara itu, pendapat lain menyebutkan bahwa gaya kepemimpinan adalah pola tingkah laku (kata-kata dan tindakan-tindakan) dari seorang pemimpin yang dirasakan oleh orang lain. ${ }^{7}$

Ngalim Purwanto mengemukakan empat gaya kepemimpinan termasuk gaya kepemimpinan kepala sekolah yakni:gaya otoriter, pseudodemokratis, gayalaisez faire (gaya bebas) dan gaya demokratis. ${ }^{8}$

1) gaya kepemimpinan otoriter

Kata otoriter atau otokrat berasal dari kata autos yang berarti sendiri dan kratos yang berate kekuasaan dan kekuatan sedangkan secara etimologi otoriter atau otokrat berarti penguasaan absolute. ${ }^{9}$ Gaya kepemimpinan seperti ini identik dengan seorang diktator, bahwa memimpin adalah menggerakkan dan memaksa kelompok. Adapun indicator dari kepemimpinan otoriter yaitu a). pemimpin (kepala sekolah) mempunyai wewenang penuh terhadap kebijakan dan penetapan peraturan sekolah, b) teknik dan langkah-langkah aktivitas ditentukan oleh pemimpin sehingga membatasi kreativitas, c) pemimpin biasanya mendikte tugas pekerjaan khusus dan teman sekerja setiap anggota, d) pemimpin cenderung bersikap pribadi atau tidak mau menerima kritikan dari bawahannya, e) dalam membuat kebijakan dan keputusan organisasi adalah tanggung jawab pemimpin sedangkan hak dan kewajiban bawahan adalah melaksanakan hasil berfikir atasan tanpa boleh bertanya dan membuat kesalahan. ${ }^{10}$

2) Gaya kepemimpinan pseudo-demokratis

${ }^{5}$ Endang Mulyasa, Manajemen Berbasis Sekolah, Konsep,Strategi dan Implementasi, (Bandung: Remaja Rosdakarya, 2004), h. 108.

6Bryan Johannes Tampi, Pengaruh Gaya Kepemimpinan dan Motivasi Terhadap Kinerja Karyawan, journal “Acta Diurna” vol 03. no. 04. Tahun 2014.

7Hersey, Kunci Sukses Pemimpin Situasional, (Jakarta: Delaprasata, 2004), h. 29.

${ }^{8}$ Ngalim Purwanto dan Sutadji Djojopranoto, Administrasi Pendidikan, (Jakarta: Mutiara Sumber Widya, 1997), h. 26.

${ }^{9}$ Kartini Kartono, Pemimpin dan Kepemimpinan, (Jakarta: RajaGrafindo Persada, 2016), h. 71.

${ }^{10}$ Hadari Nawawi, Manajemen Sumber Daya Manusia,(Yogyakarta: Gajah Mada Univessity Press, 2003), h. 103. 


\section{0 | Nursam}

Istilah pseudo berarti palsu. Pseudo demokratis berarti bukan atau tidak demokratis. Gaya kepemimpinan seperti ini sebenarnya otokratis, tetapi dalam kepemimpinannya ia member kesan demokratis. Seorang pemimpin yang bersifat pseudo-demokratis sering memakai "topeng". Ia pura-pura memperlihatkan sifat demokratis di dalam kepemimpinannya. Ia memberi hak dan kuasa kepada guru-guru untuk menetapkan dan memutuskan sesuatu, tetapi sesungguhnya ia bekerja dengan perhitungan. Ia mengatur siasat agar kemauannya terwujud kelak. ${ }^{11}$

Dengan tingkah laku, bahasa yang dipakai, dan sikapnya, ia ingin member kesan bahwa ia adalah pemimpin yang sungguh-sungguh demokratis. Demikian pula dengan pekerjaannya di sekolah, ia berusaha supaya di dalam pergaulan disenangi dan disegani. Ia sangat sopan dan selalu ingin memberi pertolongan kepada bawahannya, jika diminta; tetapi sifatsifat dan sikap itu ditonjolkan dengan maksud supaya mendapat kepercayaan dari pihak guru yang dikasihinya.

Masalah-masalah yang dihadapi di sekolah diperbincangkan terlebih dahulu dengan guru-guru yang berpengaruh sebelum dibawa ke dalam siding dewan guru-guru. Ia yakin bahwa setiap usul yang bertentangan dengan perbincangan dan putusan bersama guru-guru itu pasti akan ditolak di dalam rapat. Acara rapat dewan guru disusun oleh suatu panitia yang bekerja sama dengan kepala sekolah. Di dalam rapat ia banyak memberi kesempatan kepada guru untuk mengemukakan pendapat dan saran.Ia ingin memberi kesan bahwa ia sungguh-sungguh memperhatikan pendapat dan saran itu, tetapi sebenarnya ia licik sekali dan memanipulasi sedemikian rupa sehingga pendapatnyalah yang harus disetujui dan diterima rapat. Jika ada guru-guru yang tidak dapat menyetujui pendapat, mereka tidak berani beraksi dan menentangnya.

Sebagai akibatnya, setiap tahun ada guru yang meminta pindah ke sekolah lain. Bagi pemimpin seperti itu, kepemimpinan demokratis berarti memberi bimbingan dengan lemah-lembut dalam mengerjakan hal-hal yang dikehendakinya supaya melakukannya. Demikianlah sifat seorang pemimpin yang "pseudo-demokratis" (pseudo berarti palsu). Ia sebenarnya bersifat otokratis, tetapi dalam kepemimpinanya ia memberi kesan demokratis. Cara memimpin seperti itu disebut juga dengan istilah diplomatic manipulation atau manipulasi politik.

3) Gaya kepemimpinan bebas (laissez faire)

Gaya kepemimpinan bebas ini mempunyai arti gaya kepemimpinan yang membiarkan orang berbuat sekehendaknya. Gaya kepemimpinan ini sang pemimpin praktis tidak memimpin. Pemimpin seperti ini sama sekali tidak memberikan control dan koreksi terhadap pekerjaan para bawahan atau anggotanya. ${ }^{12}$

\footnotetext{
11Soekarto Indrafachrudi, Mengantar Bagaimana Memimpin Sekolah yang Baik, (Jakarta: Ghalia Indonesia, 2000), h. 26.

${ }^{12}$ Kartini Kartono, Pemimpin dan Kepemimpinan, h. 71.
} 
Sistem kepemimpinan ini, tidak dapat dihindarkan ekses negatif, konflik dan kesimpangsiuran kerja akan wewenang, hingga masing-masing individu saling bersaing agar pendapatnya dapat dilaksanakan, saling ada argumentasi, ada kekuatan dan akhirnya terjadi perselisihan, karena seorang pemimpin menyatukan atau mengarahkan, mengkoordinir berdasarkan konsep tertentu yang semestinya diperlukan dalam mengatasi kemelut yang terjadi dalam suatu kelompok yang memiliki banyak perbedaan cita-cita, perbedaan kecakapan, sifat khas kepribadian yang unik.

Rapat dewan guru sering diadakan dan biasanya berlangsung lama. Setiap guru ingin memperdengarkan suaranya di dalam rapat tersebut yang berlangsung tanpa susunan acara yang tersusun dengan rapi dan sistematis. Ada kalanya rapat diadakan jika diminta oleh seorang atau beberapa guru saja. Kadang-kadang pimpinan rapat diserahkan kepada salah seorang guru yang dianggap cukup cakap. Sementara rapat itu berlangsung, kepala sekolah meninggalkan rapat dan melakukan tugas lain. Sering rapat tersebut tidak menghasilkan apa-apa karena pembicaraan tanpa arah.

\section{4) Gaya kepemimpinan demokratis}

Kepemimpinan demokratis berorientasi pada manusia dan memberikan bimbingan yang efesien kepada bawahannya. Terdapat koordinasi pekerjaan semua bawahan dengan penekanan pada rasa tanggung jawab internal dan kerjasama yang baik. Kekuatan kepemimpinan demokratis bukan terletak pada person atau individu pemimpin, akan tetapi kekuatannya justru terletak pada partisipasi aktif dari setiap anggota kelompok. ${ }^{13}$ Indicator penerapan kepemimpinan kepala sekolah yang demokratis yaitu a) senantiasa meminta pendapat/melibatkan guru dan staf sebelum menetapkan kebijakan yang diambil, b) menerapkan penghargaan bagi guru yang memiliki kompetensi bagus, dan pembinaan bagi guru dan staf yang malas, c) kepala sekolah memberikan petunjuk yang jelas kepada seluruh personil dalam pelaksanaan program kerja sekolah, d) kepala sekolah senantiasa bekerjasama dengan segenap komponen di sekolah dalam mengevaluasi setiap program yang telah berjalan, e) kepala sekolah menerapkan kedisiplinan di sekolah, f) bertindak dengan menggunakan prinsip-prinsip keadilan. ${ }^{14}$

Setiap individu yang diberi tugas atau kepercayaan untuk bekerja pada suatu organisai tertentu diharapkan mampu menunjukkan kinerja yang memuaskan dan memberikan konstribusi yang maksimal terhadap pencapaian tujuan oraganisasi tersebut. Nanang Fatah berpendapat bahwa kinerja atau performance adalah penampilan atau untuk kerja, atau cara menghasilkan sesuatu (prestasi); kinerja organisasi berkaitan dengan daya untuk kerja mencapai suatu tujuan dan hasil yang digunakan. ${ }^{15}$ Guru

${ }^{13}$ Kartini Kartono, Pemimpin dan Kepemimpinan, h 72.

${ }^{14}$ Sudarwan Danim, Menjadi Komunitas Pembelajar, (Cet. I; Jakarta: Bumi Aksara, 2003), h. 183.

${ }^{15}$ Nanang Fattah, Konsep Manajemen Berbasis Sekolah dan Dewan Sekolah, (Bandung: Pustaka Bani Quraisy, 2004), h. 61. 


\section{2 | Nursam}

pemimpin diri adalah guru yang memiliki pola pikir,perilaku dan tanggung jawab mengatasi ancamandipaksakan kepadanya, inisiatif, kreatif, inovatif, dan mampumemimpin dirinya sendiri. Seorang kepala sekolah yang dapat mendesain, mendirikan sistem, yang mempengaruhi dan membentuk guru menjadi pemimpin mandiri adalah pemimpin super. ${ }^{16}$

Indikator kinerja guru antara lain:

1)Kemampuan membuat perencanaan dan persiapan mengajar, Perencanaan pembelajaran adalah suatu proses pembuatan rencana, model, pola, bentuk, kunstruksi yang melibatkan, guru, peserta didik, serta fasilitas lain yang dibutuhkan yang tersusun secara sitematis agar terjadi proses pembelajaran yang efektif dan efisien dalam mencapai tujuan pembelajaran yang telah ditetapkan. ${ }^{17}$

2) Penguasaan materi yang diajarkan, Kemampuan dalam penguasaan materi pelajaran sesuai dengan bidang studi yang diajarkan adalah salah satu tingkat keprofesionalan seorang guru. Kemampuan penguasaan materi memungkinkannya membimbing peserta didik memenuhi standar kompetensi. Kehadiran seorang guru haruslah seorang yang memang profesional dalam arti memiliki ketrampilam dasar mengajar yang baik, memahami atau menguasai bahan dan memilliki loyalitas terhadap tugasnya sebagai guru. Dengan demikian guru dituntut harus untuk senantiasa meningkatkan kinerjanya. ${ }^{18}$

3)Penguasaan metode dan strategi mengajar, Metode pembelajaran merupakan salah satu prasyarat dalam menentukan keberhasilan seorang pendidik. Karena keberhasilan atau kegagalan seorang pendidik dalam menjalankan pembelajran banyak ditentukan oleh kecakapannya dalam memilih dan menggunakan metode pembelajaran. Hal senada juga disampaikan oleh Abuddin Nata juga disampaikan oleh Abuddin Nata bahwa memiliki kedudukan yang amat strategis dalam mendukung keberhasilan pembelajaran. ${ }^{19}$ Oleh karena itu para ahli pendidikan sepakat bahwa seorang pendidik yang ditugaskan mendidik di sekolah, haruslah pendidik yang profesional, yaitu pendidik yang ditandai memiliki penugasan yang prima terhadap metode pembelajaran. Dengan mempelajari Strategi Belajar Mengajar berarti setiap guru mulai memasuki suatu kegiatan yg bernilai edukatif. Nilai edukatif mewarnai interaksi yang terjadi antara guru dgn ank didik. Interaksi yg bernilai edukatif dikarenakan kegiatan belajar mengajar yang dilakukan, diarahkan untuk mencapai tujuan tertentu yang telah dirumuskan sebelum pengajaran dilakukan. Guru dengan sadar

${ }^{16}$ Hilal Mahmud, "Building Effective School Culture Through VisionaryLeadership,Http//www. Hilal Mahmud Institut Agama Islam Negeri Palopo Email yang diveriikasi di iainpalopo.ac.id-Beranda, (Jurnal: Tahun 2017 Akses tanggal, 24 Maret 2019).

17Moh. Solihin, Etika Profesi Keguruan, (Jember: STAIN Jember Press, 2013), h. 51.

18Moh. Solihin, Etika Profesi Keguruan, h. 51.

${ }^{19}$ Abuddin Nata, Perspektif Islam tentang Strategi Pembelajaran, (Cet. I; Jakarta: Kencana Prenada Media Group, 2009), h. 176. 
merencanakan kegiatan pengajaran secara sistematis dgn memanfaatkan segala sesuatu guna kepentingan pembelajaran.

4) Pemberian tugas-tugas kepada siswa, Tugas merupakan suatu pekerjaan yang harus diselesaikan. Pemberian tugas sebagai suatu metode mengajar merupakan suatu pemberian pekerjaan oleh guru kepada siswa untuk mencapai tujuan pengajaran tertentu. Dengan pemberian tugas tersebut siswa belajar, mengerjakan tugas. Dalam melaksanakan kegiatan belajar, siswa diharapkan memperoleh suatu hasil ialah perubahan tingkah laku tertentu sesuai dengan tujuan yang telah ditetapkan. Tahap terakhir dan pemberian tugas ini adalah resitasi yang berarti melaporkan atau menyajikan kembali tugas yang telah dikerjakan atau dipelajar.

5) Kemampuan mengelola kelas, Keterampilan mengelola kelas merupakan kemampuan guru dalam mewujudkan dan mempertahankan suasana belajar mengajar yang optimal. Kemampuan ini erat kaitannya dengan kemampuan guru untuk menciptakan kondisi yang menguntungkan, menyenangkan peserta didik dan penciptaan disiplin belajar secara sehat. Mengelola kelas meliputi mengatur tata ruang kelas untuk pebelajaran dan menciptakan iklim pembelajaran yang kondusif. Dalam kaitan ini sedikitnya terdapat tujuh hal yang harus diperhatikan yaitu ruang belajar, pengaturan sarana belajar, susunan tempat duduk, penerangan, suhu, pemanasan sebelum masuk ke materi yang akan dipelajari.

6) Kemampuan melakukan penilaian dan evaluasi, A. Tabrani Rusyan dkk, menyarankan bahwa dalam rangka mengatasi permasalahanpermasalahan global yang sering terjadi di sekolah, maka perlu diterapkan budaya kinerja guru dalam proses pembelajaran. Adapun indikator kinerja guru dapar dilihat sebagai berikut: (1) Meningkatkan mutu pembelajaran sesuai dengan kebutuhan dan tuntutan para siswa, (2) Menggalakkan penggunaan alat dan media pendidikan dalam proses pembelajaran, (3) Mendorong lahirnya "Sumber Daya Manusia" yang berkualitas melalui proses pembelajaran yang efektif dan efisien, (4) Menata pendayagunaan proses pembelajaran, sehingga proses pembelajaran berdaya guna dan berhasil guna, (5) Membina peserta didik yang menghargai nilai-nilai unggul dalam proses pembelajaran, (6) Memotivasi peserta didik, menghargai, dan mengejar kualitas yang tinggi melalui proses pembelajaran, (7) Meningkatkan proses pembelajaran sesuai dengan kebutuhan globalisasi, (8) Memberi perhatian kepada peserta didik yang berbakat, (9) Mengubah peserta didik untuk berorientasi kepada kekaryaan bukan kepada ijazah, (10) Membudayakan sikap kritis dan terbuka sebagai syarat tumbuhnya pola pikir siswa yang lebih demokratis, (11) Membudayakan nilai-nilai yang mencintai kualitas kepada peserta didik, membudayakan sikapn kerja keras, produktif, dan disiplin. ${ }^{20}$

Ada beberapa penelitian dilakukan berkenaan dengan dengan kinerja guru. Hasil penelitian Tifyani menyimpulkan bahwa kaya kepemimpinan

${ }^{20}$ Tabrani Rusyan dkk, Upaya Meningkatkan Budaya Kinerja Guru, (Cianjur: Dinamika Karya Cipta, 2000), h. 11. 


\section{4 | Nursam}

berpengaruh terhdapa kinerja guru. ${ }^{21}$ Kinerja guru turut berpengaruh terhadap hasil pencapaian yang diperoleh oleh siswa. Hasil penelitian Zulkaida menujukkan bahwa kinerja guru dalam pembelajaran dapat meningkatkan prestasi belajar siswa. ${ }^{22}$

Fokus penelitian ini membahas tentang gaya kepemimpinan kepala sekolah dalam menegembangkan kinerja guru SMP Negeri 2 Baebunta dengan deskripsi focus 1) mendeskripsikan gaya kepemimpinan kepala sekolah di SMP Negeri 2 Baebunta, 2) mengetahui kinerja guru di SMP Negeri 2 Baebunta, 3) memahami faktor internal yang berkontribusi dalam mengembangkan kinerja pendidik di SMP Negeri 2 Baebunta. 4) memahami faktor eksternal yang berkontribusi dalam mengembangkan kinerja pendidik di SMP Negeri 2 Baebunta. Penelitian in diharapkan dapat digunakan sebagai informasi dalam mengembangkan kinerja pendidik dan pengelolaan peserta didik di sekolah-sekolah khususnya di SMP Negeri 2 Baebunta.

\section{Metode}

Penelitian ini merupakan penelitian deskriptif kualitatif dengan pendekatan religious, pendekatan pegagogik, dan pendekatan sosiologis. Adapun subjek dalam penelitian ini yakni kepala sekolah, guru dan siswa sedangkan objek penelitian ini yakni kinerja guru SMP Negeri 2 Baebunta, faktor internal dan eksternal yang berkontribusi dalam mengembangkan kinerja pendidik di SMP Negeri 2 Baebunta, serta gaya kepemimpinan kepala sekolah. Data diperoleh melalui observasi, wawancara dan dokumentasi. Data dianalisis melaui triangulasi reduksi data, penyajian data dan penarikan kesimpulan.

\section{Gaya Kepemimpinan Kepala Sekolah}

Gaya kepemimpinan yang digunakan oleh kepala Sekolah di SMP Negeri 2 Baebunta dalam mengembangkan kinerja guru cenderung menerapkan gaya demokratis seperti pelibatan personil sekolah dalam rapat, pengabilan keputusan, pendelegasian tugas/perintah, dan kegiatan sekolah. Meskipun kepala sekolah cenderung menerapkan gaya kepemimpinan demokratis namun tidak menutup kemungkinan kepala sekolah menerapkan gaya kepemimpinan yang lain seperti gaya otoriter diterapkan oleh kepala sekolah apabila ada kebutuhan/masalah mendesak atau tindakan disipliner bagi guru yang seblumnya pernah diberikan teguran. Kepala sekolah juga menerapkan gaya kepemimpinan Laissez Faire namun hanya bagi guru-guru yang telah menunjukkan kinerja yang baik.

${ }^{21}$ Tifyani, Pengaruh Gaya Kepemimpinan dan Kemampuan Supervisi Kepala Madrasah terhadap Kinerja Guru pada MI Swasta se Kecamatan Sumberlawang Kabupaten Sragen, (Tesis: IAIN Surakarta, 2016), h. ix.

22Zulkaida, Pengaruh Kinerja Guru dalam Pembelajaran Terhadap Prestasi Belajar Siswa di SMP Negeri 7 Kendari, (Kendari: IAIN Kendari, 2014), h. ix. 


\section{Kinerja Guru}

Kinerja guru merupakan perilaku yang ditunjukkan oleh guru dalam melaksanak tugasnya. Kinerja guru yang ditunjukkan oleh guru di SMP Negeri 2 Baebunta dapat dilihat dari dua aspek yakni:

1. Penampilan kinerja

Seorang guru sejatinya selalu mengembangkan keterampilan mengajar yang sesuia dengan kemajuan zaman dan lingkungan local dimana proses pendidikan pendidikan dilaksakana. Penampilan kinerja guru ditunjukkan dalam a) perencanaan pembelajaran yakni persiapan perangkat pembelajaran yang menjadi pegangan bagi daalam melaksanakan pembelajaran di kelas. Perangkat pembelajaran disiapkan oleh guru sebelum melaksanakan proses pembelajaran baik perengkat pembelajaran dibuat pada saat MGMP atau dibuat secara mandiri; b) pelaksanaan pembelajaran yakni pelaksanaan proses pembelajaran baik di dalam kelas maupun diluar kelas. Aktivitas pelaksanaan pembelajaran terdiri dari 1) kegiatan awal dimana kinerja terlihat dari keampuan guru dalam membangun motivasi siswa untuk belajar, memberikan garis besar tujuan materi yang akan dipelajari dan kemampuan guru untuk mengaitkan pengalaman siswa dengan materi yang akan dipelajari. 2) kegiatan inti kinerja guru terlihat dari kemampuan dalam menguasai pembelajaran, kemampuan guru menjelaskan, dan penggunaan media pembelajaran yang bervariatif. 3) kegiatan akhir kinerja guru terlihat dari kemampuan guru dalam memberikan umpan balik, pemberikan tugas, pemberian kesimpulan, dan pelaksanaan penilain.

\section{Hasil kerja}

Hasil kerja merupakan pencapaian nilai akhir yang capai oleh peserta didik. Ada tigas hasil penilaian yang menjadi acuan dalam melihat hasi kerja guru yaitu 1) Nilai harian yang merupakan pencapaian siswa untuk melihat penguasaan siswa pada setiap kompetensi; 2) Nilai UTS menjadi bahan analisis guru untuk melihat kelemahan-kelemahan siswa pada materi tertentu sehingga apabila ada siswa yang belum menguasai materi maka akan diberikan remedial sehingga dapat mencapai nilai KKM; 3) Nilai UAS menujukkan pencapaian siswa dalam mengikuti proses pembelajaran selama satu semester dan nilai ini menjadi bahan evaluasi untuk perbaikan proses pembelajaran pada semester berikutnya. 


\section{Faktor Internal yang mengembangkan Kinerja Guru}

Ada dua faktor internal yang memengaruhi kinerja guru yakni faktor yang menjadi kekuatan dan faktor yang menjadi kelemahan. Faktor kekuatan merupak faktor pendorong terjadinya pengembangan kinerja guru dalam melaksanakan tuganya sedangkan faktor kelemahan merupakan faktor penghambat dalam proses pengembagan kinerja guru di SMP Negeri 2 Baebunta.

1. Sarana dan prasarana, secara garis besar sarana dan prasarana di SMP Negeri 2 Baebunta cukup memadai untuk mendukung terlaksananya proses pembelajaran dengan baik namun kelemahan yang dihadapi yaitu belum ada laboratorium untuk mendukung pembelajaran praktek.

2. Guru, kegiatan yang mendukung dalam menegembangkan kinerja guru yakni mengikuti berbagai diklat dan pelatihan sehingga dapat mendorong peningkatan kinerja guru. Adapun kelemahannya yakni masih ada beberapa guru yang berstatus tenaga honorer sehingga guru tersebut masih disibukkan dengan aktivitas lain di luar aktivitas sekolah.

3. Kepala sekolah, dalam mendukung pengembangan kinerja guru kepala sekolah melakukan kunjungan kelas dan memberikan motivasi kepada guru. Disisi lain kepala sekolah menghadapi beberapa masalah dalam meningkatkan kinerja guru seperti masalah disiplin guru, masalah hubungan interpersonal, masalah internal keuangan, masalah kebijakan kepala sekolah serta masalah kepala sekolah dengan masyarakat. Selain itu kepala sekolah juga masih kurang tegas terhadap guru yang lalai dalam melaksanakan tugasnya.

\section{Faktor Eksternal yang mengembangkan Kinerja Guru}

Faktor ekternal yang berkontribusi terhadap pengembangan kinerja guru di SMP Negeri 2 Baebunta dapat dilihat dari dua arah yakni peluang dan tantangan yang dihadapi oleh sekolah.

1. Faktor kebijakan pemerintah, pemerintah mendorong peningkatan kinerja guru dengan melaksanakan berbagai program pengembangan kompetensi melalui diklat ataupun pelatihan. Sedangkan tantangan yang dihadapi yakni belum adanya dukungan secara finansial pemerintah bagi tenaga honorer dan juga kebijakan kewajiban guru untuk mengajar 24 jam pelajaran untuk mendapatkan tunjangan sehingga guru kseulitan untuk mendapatkan jam tambahan atau bahkan mendapatkan tambahan jam pelajaran di sekolah lain yang jaraknya cukup jauh.

2. Faktor teknologi informasi, pemanfaatan teknologi sangat membantu guru dalam melakasanakan proses pembelajaran di dalam kelas. Perkembnagan teknologi juga membantu guru dan siswa dalam memeroleh berbagai informasi yang dibutuhkan. Sedangkan tantangan yang dihadapi yakni masih ada guru yang kurang memahami dan belum memanfaatkan teknologi secara maksimal.

3. Kerja sama antara pihak sekolah, pola kerjasama yang baik setiap komponen sekolah menjadi faktor yang mendukung pengembangan kinerja guru seperti kepala sekolah yang memberikan arahan bagi guru-guru 
menghadapi kesulitan begitupula sesama guru dapat saling membantu dan membegikan informasi berkenaan dengan masalah-masalah yang dihadapi.

\section{Kesimpulan}

Gaya kepemimpinan kepala sekolah di SMP Negeri 2 Baebunta secara umum menerapkan gaya demokratis dan gaya otoriter dan Laissez Faire pada kondisi-kondisi tertentu. Kinerja guru terlihat dari penampilan kinerja dan hasil kerja. Penampilan ditunjukkan dengan melakukan perencanaan pembelajaran yakni penyusunan perangkat pembelajaran yang akan digunakan sebagai acuan dalam pelaksanaan pembelajaran. Penampilan kerja juga ditujukkan dengan pelaksanaan pembelajaran baik di dalam ruang kelas maupun diluar ruang kelas.

Faktor internal yang mendukung pengembangan kinerja guru yakni sarana dan prasaran sekolah yang cukup memadai, ikut serta guru dalam berbagai diklat dan pelatihan serta faktor kepala sekolah yang mendukung dan memberikan motivasi kepada guru. Sedangkan faktor kelemahannya yakni belum ada laboratorium untuk melaksanakan pembelajaran praktikum, masih ada guru yang berstatus honorer, masalah disiplin guru, hubungan interpersonal, kebijakan kepala sekolah, hubungan kepala sekolah dengan masyarakat dan kurangnya ketegasan kepala sekolah.

Faktor eksternal yang mendukung pengembangan kinerja guru diantaranya kebijakan pemerintah dalam melaksakan program-program pengembangan kompetensi seperti dikat dan pelatihan, perkembangan teknologi memudahkan guru dan siswa dalam mengakses informasi dan kerjasama antara kompponen sekolah yang terjalin dengan baik. Sedangkan tantangan yang dihadapi yakni belum adanya dukungan financial bagi tenaga honorer dan kewajiban guru yang banyak, masih ada beberapa guru yang belum memanfaatkan teknologi secara maksimal.

\section{Daftar Pustaka}

Burhanuddin. 1994. Analisis Administrasi: Manajemen dan Kepemimpinan Pendidikan, Jakarta: Bumi Aksara, 1994.

Danim. Sudarwan. 2003. Menjadi Komunitas Pembelajar, Cet. I; Jakarta: Bumi Aksara

Fattah. Nanang. 2004. Konsep Manajemen Berbasis Sekolah dan Dewan Sekolah, Bandung: Pustaka Bani Quraisy.

Hersey. 2004. Kunci Sukses Pemimpin Situasional, Jakarta: Delaprasata, 2004Mulyasa. Endang. Manajemen Berbasis Sekolah, Konsep,Strategi dan Implementasi, Bandung: Remaja Rosdakarya.

Indrafachrudi. Soekarto. 2000. Mengantar Bagaimana Memimpin Sekolah yang Baik, Jakarta: Ghalia Indonesia.

Kartono. Kartini. 2016. Pemimpin dan Kepemimpinan, Jakarta: RajaGrafindo Persada. 
38 | Nursam

Mahmud. Hilal. 2017. Building Effective School Culture Through Visionary Leadership, Http//www. Hilal Mahmud Institut Agama Islam Negeri Palopo Email yang diveriikasi di iainpalopo.ac.id-Beranda, Jurnal, Akses tanggal, 24 Maret 2019.

Nata. Abuddin. 2009. Perspektif Islam tentang Strategi Pembelajaran, Cet. I; Jakarta: Kencana Prenada Media Group.

Nawawi. Hadari. 2001. Kepemimpinan Menurut Islam, Yogyakarta: GajahMada University Press.

Nawawi. Hadari. 2003. Manajemen Sumber Daya Manusia, Yogyakarta: Gajah Mada Univessity Press.

Purwanto. Ngalim. 2017. Administrasi dan Supervisi Pendidikan, Bandung: Remaja Rosdakarya.

Purwanto. Ngalim, Sutadji Djojopranoto. 1997. Administrasi Pendidikan, Jakarta: Mutiara Sumber Widya.

Rusyan. Tabrani et. al. 2000. Upaya Meningkatkan Budaya Kinerja Guru, Cianjur: Dinamika Karya Cipta.

Sagala. Syaiful. 2009. Kemampuan Profesional Guru dan Tenaga Kepemimpinan, Bandung: Alfabeta.

Solihin. Moh. 2013. Etika Profesi Keguruan, Jember: STAIN Jember Press.

Tampi. 2014. Bryan Johannes. Pengaruh Gaya Kepemimpinan dan Motivasi Terhadap Kinerja Karyawan, journal “Acta Diurna” vol 03. no. 04.

Tifyani. 2016. Pengaruh Gaya Kepemimpinan dan Kemampuan Supervisi Kepala Madrasah terhadap Kinerja Guru pada MI Swasta se Kecamatan Sumberlawang Kabupaten Sragen, Tesis: IAIN Surakarta.

Zulkaida. 2014. Pengaruh Kinerja Guru dalam Pembelajaran Terhadap Prestasi Belajar Siswa di SMP Negeri 7 Kendari, Kendari: IAIN Kendari. 